\title{
Tax Compliance Ditinjau dari Theory of Planned Behavior (TPB): Studi Empiris Pada Wajip Pajak Orang Pribadi dan Badan yang Terdaftar Pada KPP di Kota Palembang
}

\author{
Desy Lesmana ${ }^{1}$, Delfi Panjaitan, ${ }^{2}$ Mutiara Maimunah ${ }^{3}$
}

\author{
A R T I C L E I N F O \\ Keywords: \\ attitude, subjective norms, \\ perceived behavioral control, \\ moral obligation, and intention to \\ obey
}

\begin{abstract}
A B S T R A C T
This study aims to analyze the factors that affect the tax compliance by using Theory of Planned Behavior Approach (TPB). This study used survey design with data collection techniques by using questionnaires, where the selected respondents are taxpayers of individuals and entities registered at the KPP in the city of Palembang. The results showed that the variables that influence the intention to abide positively are the control behavioral variable and moral obligation, while the variable attitude and subjective norms do not affect it. Further testing indicates that the variable intention to abide affects compliance with taxpayers positively.
\end{abstract}

\begin{abstract}
A B S T R A K
Penelitian ini bertujuan untuk menganalisis faktor-faktor yang mempengaruhi tax compliance dengan menggunakan Pendekatan Theory Of Planned Behavior (TPB). Penelitian ini menggunakan desain survey dengan teknik pengumpulan data menggunakan kuesioner, dimana responden yang dipilih adalah wajib pajak orang pribadi dan badan yang terdaftar pada KPP di kota palembang. Hasil penelitian menunjukkan bahwa variabel yang mempengaruhi niat untuk patuh secara positif adalah variabel kontrol keprilakuan dan kewajiban moral, sementara variabel sikap dan norma subyektif tidak mempengaruhinya. pengujian lebih lanjut menunjukkan bahwa variabel niat untuk patuh mempengaruhi kepatuhan wajib pajak secara positif.
\end{abstract}

\section{PENDAHULUAN}

Pajak adalah iuran rakyat kepada negara yang diatur dengan undang-undang, dengan tidak mendapat balas jasa secara langsung. di dalam banyak literatur keuangan negara disebutkan bahwa sumber utama penerimaan negara berasal dari pajak. ini terlihat dari rata-rata penerimaan negara dari sektor perpajakan mencapai 73,4\% selama empat tahun terakhir dan sisanya sebesar $26,6 \%$ berasal dari penerimaan lain di luar pajak (penerimaan bukan pajak 26,2\% dan hibah sebesar $0,4 \%$ ). tingginya penerimaan pajak mencerminkan kemandirian suatu negara untuk membiayai pembangunan nasional. apabila penerimaan pajak tinggi maka dapat dikatakan suatu negara telah mandiri untuk membiayai pembangunannya dan semakin kecil ketergantungannya terhadap bantuan asing seperti hutang luar negeri maupun hibah. sehingga diharapkan penerimaan pajak terus meningkat setiap tahunnya.

Selain dipengaruhi oleh inflasi, besaran target penerimaan perpajakan ditentukan oleh kebijakan pemerintah terkait perpajakan, seperti perubahan besaran pendapatan tidak kena pajak (ptkp), upaya ekstensifikasi peningkatan jumlah wajib pajak, kebijakan pemberian stimulus fiskal, dan lainnya, serta upaya pemerintah melaksanakan optimalisasi tax policy and administration reform

*desylesmana@gmail.com:11delfianna_panjaitan@yahoo.com,2mutiaramai@gmail.com. 
yang meliputi reformasi di bidang administrasi, bidang peraturan perundang-undangan, bidang pengawasan dan penggalian potensi.

Namun kenyataannya, sampai saat ini penerimaan dari sektor perpajakan masih belum optimal. Belum optimalnya penerimaan di sektor perpajakan disebabkan karena masih minimnya tingkat kesadaran dan kepatuhan wajib pajak dalam membayar pajak. Seperti yang dikutip dari artikel yang ditulis oleh agung sasongko dalam www.republika.co.id (4 januari 2015), direktur jenderal kementerian keuangan fuad rahmany menyatakan tingkat kepatuhan wajib pajak di tanah air hingga saat ini masih sangat minim. Berdasarkan data kemenkeu, dari total 12 juta wajib pajak badan (non-perorangan) hanya 5 juta yang sudah menghasilkan laba usaha. Dari jumlah tersebut, hanya 550 ribu atau $11 \%$ yang rutin melaporkan surat pemberitahuan tahunan (spt tahunan) pajak penghasilan. Sedangkan wajib pajak pribadi ditengarai sebanyak 30 juta orang tidak membayar pajak.

Besarnya jumlah wajib pajak badan yang tidak melaporkan spt tahunan pph dan wajib pajak orang pribadi yang tidak membayar pajak menunjukkan bahwa kesadaran dan kepatuhan wajib pajak di indonesia masih rendah. Rendahnya kepatuhan dan kesadaran wajib pajak dapat dilihat salah satunya melalui rendahnya pelaporan spt tahunan (tarjo dan kusumawati 2005). Artikel yang dimuat oleh athurtian dalam www.okezone.com (3 maret 2015) menyebutkan bahwa target pajak yang ditetapkan dalam anggaran pendapatan belanja negara-perubahan (apbn-p) sebesar rp 1.246 triliun tidak tercapai. Realisasi penerimaan pajak tahun 2014 hanya mencapai rp 1.143 triliun atau sekitar $91,75 \%$. Hal ini tentunya akan berdampak pada berkurangnya penerimaan apbn yang mengakibatkan kerugian bagi negara.

Menurut ekonomi utama bank dunia, ndiame dop, seperti yang ditulis di bisnis.com (3 agustus 2014), melesetnya target penerimaan pajak dalam tujuh tahun terakhir dikarenakan lemahnya regulasi perpajakan dalam meningkatkan tingkat kepatuhan pajak (tax compliance). Lebih lanjut dikemukakan bahwa fenomena perpajakan di indonesia adalah sebagian besar warga indonesia, terutama orang kaya atau orang berpenghasilan menengah belum patuh membayar pajak. Masih di laman bisnis.com, pengamat perpajakan universitas indonesia, darussalam, mengatakan kepatuhan pajak di indonesia memang berada di kisaran 30\%$60 \%$ selama 4 tahun terakhir ini. Salah satu penyebab rendahnya kepatuhan membayar pajak itu adalah tingkat kepercayaan masyarakat terhadap ditjen pajak masih rendah.

Berbagai upaya pemerintah telah dilakukan untuk mendorong meningkatnya penerimaan dari sektor pajak. Direktorat jenderal pajak (djp) telah mencanangkan tahun 2015 sebagai tahun pembinaan wajib pajak dengan motto reach the unreachable, touch the untouchable. Pihak-pihak yang akan dibina oleh djp adalah kelompok orang pribadi atau badan yang belum terdaftar sebagai wajib pajak, kelompok wajib pajak terdaftar namun belum pernah menyampaikan surat pemberitahuan (spt), serta kelompok wajib pajak terdaftar yang telah menyampaikan spt, namun belum sesuai dengan kondisi yang sebenarnya. Melalui tahun pembinaan wajib pajak 2015, pemberian insentif penghapusan sanksi administrasi dimaksudkan sebagai pendorong wajib pajak agar membetulkan spt dan melunasi kekurangan pajaknya, sekaligus memberikan dukungan positif dalam pencapaian target penerimaan negara dari pajak.

Theory of planned behavior (tpb) adalah salah satu teori perilaku yang sering digunakan untuk menjelaskan perilaku kepatuhan pajak. Teori ini menjelaskan bahwa perilaku seseorang dipengaruhi oleh niat yang dimiliki. Sementara niat seseorang dibentuk oleh sikap terhadap perilaku (attitude toward the behavior), norma subyektif (subjective norm), dan kontrol keperilakuan yang dipersepsikan (perceived behavioral control) melalui keyakinan yang dimilikinya. Blanthorne (2000) dan bobek (2003) dalam mustikasari (2007) membuktikan bahwa perilaku tidak patuh (noncompliance) wajib pajak sangat dipengaruhi oleh sikap, norma subyektif, dan kontrol keperilakuan yang dipersepsikan.

Penelitian ini memfokuskan pada kepatuhan wajib pajak terhadap spt tahunan pajak penghasilan orang pribadi dan badan karena pajak penghasilan adalah salah satu jenis pajak yang dipungut oleh pemerintah pusat, berdasarkan undangundang nomor 36 tahun 2008 tentang perubahan atas undang-undang nomor 7 tahun 1983 tentang pajak penghasilan. Pajak penghasilan melekat pada subyeknya. Subjek pajak akan dikenai apabila ia menerima atau memperoleh penghasilan. Penulis tertarik untuk melakukan penelitian tentang tax compliance ditinjau dari theory of planned behavior (tpb): studi empiris pada wajib pajak orang pribadi dan badan yang terdaftar pada kpp di kota palembang.

Masalah yang menjadi pokok bahasan penelitian ini adalah apakah sikap, norma subyektif, kontrol keperilakuan yang dipersepsikan, dan 
kewajiban moral mempengaruhi niat untuk patuh serta pakah niat untuk patuh mempengaruhi kepatuhan wajib pajak (tax compliance). Sejalan dengan permasalahan, maka tujuan penelitian ini adalah untuk menguji secara empiris pengaruh sikap, norma subyektif, kontrol keperilakuan yang dipersepsikan, dan kewajiban moral terhadap niat untuk patuh serta pengaruh niat untuk patuh terhadap kepatuhan pajak (tax compliance).

\section{TEORI}

Theory Of Planned Behavior (TPB)

Menurut theory of planned behavior, perilaku manusia didasarkan atas tiga jenis pertimbangan yaitu:

Behavioral beliefs (keyakinan perilaku), yaitu keyakinan tentang kemungkinan hasil dari perila$\mathrm{ku}$ dan evaluasi atas hasil tersebut (beliefs strength and outcome evaluation). Keyakinan perilaku menghasilkan sikap terhadap perilaku baik atau buruk;

Normative beliefs (keyakinan normatif), yaitu keyakinan tentang harapan normatif orang lain dan motivasi untuk memenuhi harapan tersebut (nomative beliefs and motivation to comply). Keyakinan normatif mengakibatkan tekanan sosial yang dirasakan atau norma subyektif (subjective norm); dan

Control beliefs (keyakinan kontrol), yaitu keyakinan tentang adanya faktor yang dapat memfasilitasi atau menghambat perilaku yang akan ditampilkan (control beliefs) dan persepsi tentang seberapa kuat faktor tersebut (perceived power). Keyakinan kontrol menimbulkan kontrol keperilakuan yang dipersepsikan.

Dalam kombinasinya, sikap terhadap perilaku (attitude toward the behavior), norma subyektif (subjective norm), dan kontrol keperilakuan yang dipersepsikan (perceived behavioral control) mengarah pada pembentukan niat perilaku (intention) (ajzen, 2002).

Relevansi dari theory of planned of behavior dengan penelitian ini adalah bahwa perilaku patuh atau tidak patuh wajib pajak dalam memenuhi kewajiban perpajakannya dipengaruhi oleh niat yang dimiliki oleh wajib pajak. Apabila wajib pajak memiliki niat untuk patuh terhadap kewajiban perpajakannya maka akan terjadi perilaku tax compliance (kepatuhan pajak). Dimana niat untuk patuh ditentukan oleh tiga faktor yaitu sikap, norma subyektif dan kontrol keperilakuan yang dipersepsikan yang dimiliki oleh wajib pajak.
Gambar 1. Theory of planned behavior

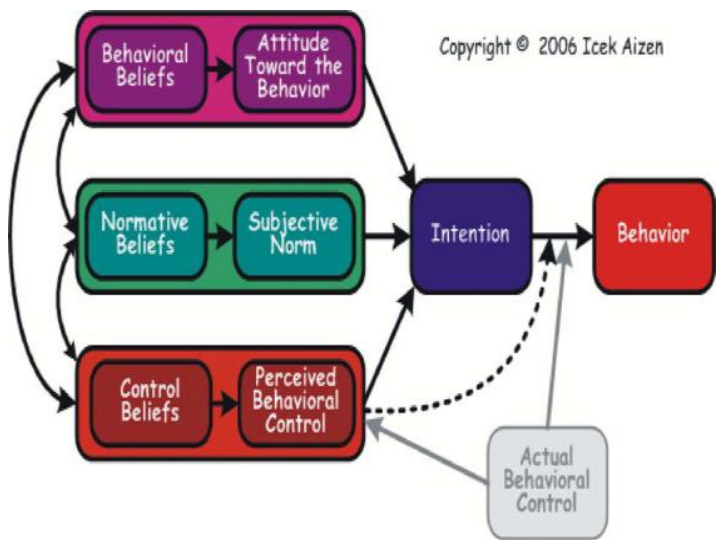

Sumber: Ajzen, Icek. 2002. Constructing a TPB Questionnaire: Conceptual and Methodological Consideration. September (Revised January, 2006).

\section{Tax Compliance (Kepatuhan Pajak)}

Kepatuhan dalam hal perpajakan berarti keadaan wajib pajak yang melaksanakan hak, dan khususnya kewajibannya, secara disiplin sesuai peraturan perpajakan yang berlaku. Kepatuhan dimaksud adalah terkait dengan bagaimana melaporkan semua informasi yang diperlukan tepat pada waktunya, mengisi secara benar jumlah pajak terutang, dan membayar pajak tepat pada waktunya (pangestu dan rusmana 2012). Kriteria wajib pajak patuh yang disebutkan dalam pasal 2 peraturan menteri keuangan nomor 74/pmk.03/2012 tentang tata cara penetapan dan pencabutan wajib pajak dengan kriteria tertentu dalam rangka pengembalian pendahuluan kelebihan pembayaran pajak menyebutkan:

1. Untuk dapat ditetapkan sebagai wajib pajak dengan kriteria tertentu, wajib pajak harus memenuhi persyaratan sebagai berikut:

2. Tepat waktu dalam menyampaikan surat pemberitahuan;

3. Tidak mempunyai tunggakan pajak untuk semua jenis pajak, kecuali tunggakan pajak yang telah memperoleh izin mengangsur atau menunda pembayaran pajak;

4. Laporan keuangan diaudit oleh akuntan publik atau lembaga pengawasan keuangan pemerintah dengan pendapat wajar tanpa pengecualian selama 3 (tiga) tahun berturut-turut; dan

5. Tidak pernah dipidana karena melakukan tindak pidana di bidang perpajakan berdasarkan putusan pengadilan yang telah 
mempunyai kekuatan hukum tetap dalam jangka waktu 5 (lima) tahun terakhir.

Tepat waktu penyampaian surat pemberitahuan sebagaimana dimaksud dalam pasal 2 huruf a tersebut meliputi:

1. Penyampaian surat pemberitahuan tahunan selama 3 (tiga) tahun pajak terakhir yang wajib disampaikan sampai dengan akhir tahun sebelum tahun penetapan wajib pajak dengan kriteria tertentu dilakukan tepat waktu;

2. Penyampaian surat pemberitahuan masa yang terlambat dalam tahun terakhir untuk masa pajak januari sampai november tidak lebih dari 3 (tiga) masa pajak untuk setiap jenis pajak dan tidak berturut-turut; dan

3. Surat pemberitahuan masa yang terlambat sebagaimana dimaksud pada huruf $b$ telah disampaikan tidak lewat dari batas waktu penyampaian surat pemberitahuan masa masa pajak berikutnya.

Menurut Nurmantu (2003) dalam Widodo, Djefris dan Wardhani (2010:68-69), terdapat dua macam kepatuhan yaitu kepatuhan formal dan kepatuhan material. Kepatuhan formal adalah suatu keadaan dimana wajib pajak memenuhi kewajibannya secara formal sesuai dengan ketentuan dalam undang-undang perpajakan. Misalnya ketentuan tentang batas waktu penyampaian SPT PPH tahunan adalah selambat-lambatnya 3 bulan setelah berakhirnya tahun pajak untuk wajib pajak orang pribadi dan 4 bulan untuk wajib pajak badan, yang pada umumnya adalah tanggal 31 Maret dan 30 April. Jika wajib pajak menyampaikan spt pph tersebut sebelum tanggal batas waktu tersebut maka dapat dikatakan bahwa wajib pajak tersebut telah memenuhi kepatuhan formal.

Kepatuhan material adalah suatu keadaan dimana wajib pajak secara substantif (hakekat) memenuhi semua ketentuan material perpajakan, yakni sesuai isi dan jiwa undang-undang perpajakan. Kepatuhan material dapat juga meliputi kepatuhan formal. Jadi wajib pajak yang memenuhi kepatuhan material dalam mengisi SPT $\mathrm{PPH}$, adalah wajib pajak yang mengisi dengan jujur, baik dan benar atas SPT tersebut sehingga sesuai dengan ketentuan dalam undang-undang perpajakan dan menyampaiakan ke KPP sebelum batas waktu.

Adapun faktor-faktor yang mendorong kepatuhan wajib pajak yaitu: (1) kemudahan memperoleh informasi melalui sistem perpajakan, (2) keberadaan peraturan perpajakan yang baik, (3) tarif pajak yang baik dan tidak memberatkan, (4) kemudahan proses pelaporan, dan kenyamanan di kantor pajak (Widodo, Djefris dan Wardhani 2010:214). Wajib Pajak Undang-undang nomor 16 tahun 2009 tentang perubahan keempat atas undang-undang nomor 6 tahun 1983 tentang ketentuan umum dan tata cara perpajakan pasal 1 ayat 2 mendefinisikan wajib pajak yaitu:

Wajib pajak (WP) adalah orang pribadi atau badan, meliputi pembayar pajak, pemotong pajak, dan pemungut pajak, yang mempunyai hak dan kewajiban perpajakan sesuai dengan ketentuan peraturan perundang-undangan perpajakan. Wajib pajak dibedakan menjadi 2 yaitu wajib pajak orang pribadi dan wajib pajak badan. Selanjutnya dalam undang-undang tersebut yang dimaksud badan adalah: sekumpulan orang dan/atau modal yang merupakan kesatuan baik yang melakukan usaha maupun tidak yang meliputi perseroan terbatas, perseroan komanditer, perseroan lainnya, badan usaha milik negara dengan nama dan dalam bentuk apapun, firma, kongsi, koperasi, dana pensiun, persekutuan, perkumpulan, yayasan, organisasi massa, organisasi sosial politik, atau organisasi lainnya, lembaga dan bentuk badan lainnya termasuk kontrak investasi kolektif dan bentuk usaha tetap.

\section{Sistem pemungutan pajak}

Setelah reformasi perpajakan, pemungutan pajak langsung dan pajak tidak langsung digunakan satu sistem yaitu sistem berbayar sendiri (self assessment). Sistem ini dipilih karena menurut undang-undang perpajakan yang baru wajib pajak diberi kepercayaan sepenuhnya untuk melaksanakan kewajiban perpajakannya (Salamun 1991:111-112). Waluyo (2011) menyebutkan bahwa sistem self assessment adalah sistem pemungutan pajak yang memberi wewenang, kepercayaan, tanggung jawab kepada wajib pajak untuk menghitung, memperhitungkan, membayar, dan melaporkan sendiri besarnya pajak yang harus dibayar.

\section{Surat Pemberitahuan (SPT)}

Surat pemberitahuan (SPT) adalah surat yang digunakan oleh wajib pajak untuk melaporkan penghitungan dan/atau pembayaran pajak, objek pajak dan/atau bukan objek pajak, dan/atau harta dan kewajiban sesuai dengan ketentuan peraturan perundang-undangan perpajakan (Diana dan Setiawati 2009:121). SPT memiliki berbagai fungsi diantaranya bagi wajib pajak pajak penghasilan, bagi PKP dan bagi pemotong atau pemungut pajak. 
Bagi WP pajak penghasilan, SPT berfungsi sebagai sarana untuk melaporkan dan mempertanggungjawabkan penghitungan jumlah pajak yang sebenarnya terutang dan untuk melaporkan tentang:

1. Pembayaran atau pelunasan pajak yang telah dilaksanakan sendiri dan/atau melalui pemotongan atau pemungutan pihak lain dalam 1 tahun pajak atau bagian tahun pajak.

2. Penghasilan yang merupakan objek pajak dan/atau bukan objek pajak,

3. Harta dan kewajiban, dan/atau

4. Pembayaran dari pemotong atau pemungut tentang pemotongan atau pemungutan pajak orang pribadi atau badan lain dalam satu masa pajak sesuai dengan ketentuan peraturan perundangundangan perpajakan.

Bagi PKP, SPT berfungsi sebagai sarana untuk melaporkan dan mempertanggungjawabkan penghitungan jumlah pajak pertambahan nilai dan pajak penjualan atas barang mewah yang sebenarnya terutang dan untuk melaporkan tentang:

1. Pengkreditan pajak masukan terhadap pajak keluaran, dan

2. Pembayaran atau pelunasan pajak yang telah dilaksanakan sendiri oleh PKP dan/atau melalui pihak lain dalam satu masa pajak, sesuai dengan ketentuan peraturan perundang-undangan perpajakan.

Bagi pemotong atau pemungut pajak, SPT berfungsi sebagai sarana untuk melaporkan dan mempertanggungjawabkan pajak yang dipotong atau dipungut dan disetorkannya. Sehingga dapat disimpulkan fungsi SPT secara umum adalah sarana untuk mempertanggungjawabkan dan melaporkan pajak yang sebenarnya terutang oleh wajib pajak baik oleh wajib pajak pajak penghasilan, wajib pajak PKP dan pemotong atau pemungut pajak. Terdapat dua jenis SPT yaitu:

1. Spt tahunan adalah surat pemberitahuan untuk suatu tahun pajak atau bagian tahun pajak.

2. SPT masa adalah surat pemberitahuan untuk suatu masa pajak. Masa pajak adalah jangka waktu yang menjadi dasar bagi wajib pajak untuk mengitung, menyetor, dan melaporkan pajak yang terutang dalam suatu jangka watu tertentu. Masa pajak sama dengan 1 bulan kalender atau jangka waktu lain yang diatur dengan peraturan menteri keuangan paling lama 3 bulan kalender.

\section{Sikap (Attitude)}

Sikap merupakan produk dari proses sosialisasi di mana seseorang bereaksi sesuai dengan rangsang yang diterimanya (mar'at 1981:9). Menurut mustikasari (2007), sikap adalah suatu bentuk evaluasi perasaan. Sikap seseorang terhadap suatu objek adalah perasaan mendukung atau memihak (favorable) maupun perasaan tidak mendukung atau tidak memihak (unfavorable) pada obyek tersebut. Sikap mempunyai peran yang penting dalam menjelaskan perilaku seseorang dalam lingkungannya, walaupun masih banyak faktor lain yang mempengaruhi perilaku, seperti stimulus, latar belakang individu, motivasi, dan status kepribadian. Secara timbal balik, faktor lingkungan juga mempengaruhi sikap dan perilaku. Ajzen (2002) menyebutkan sikap terhadap tingkah laku (attitude toward the behavior) ditentukan oleh keyakinan perilaku (behavioral beliefs) yang dimiliki oleh seseorang.

\section{Norma subyektif (subjetive norm)}

Norma subyektif adalah persepsi individu tentang pengaruh sosial dalam membentuk perilaku tertentu (Ajzen 1988 dalam Mustikasari 2007). Norma subyektif merupakan fungsi dari harapan yang dipersepsikan individu dimana satu atau lebih orang disekitarnya (misalnya saudara, teman sejawat) menyetujui perilaku tertentu dan memotivasi individu tersebut untuk mematuhi mereka (Ajzen 1991). Ajzen (2002) menyebutkan bahwa subjective norm (norma subyektif ditentukan oleh normative beliefs (keyakinan normatif) yang dimiliki oleh seseorang yang mengakibatkan tekanan sosial yang dirasakan atau norma subyektif.

\section{Kontrol keperilakuan yang dipersepsikan (per- ceived behavioral control)}

Kontrol keperilakuan yang dipersepsikan dalam konteks perpajakan adalah seberapa kuat tingkat kendali yang dimiliki seorang wajib pajak dalam menampilkan perilaku tertentu, seperti melaporkan penghasilannya lebih rendah, mengurangkan beban yang seharusnya tidak boleh dikurangkan ke penghasilan, dan perilaku ketidakpatuhan lainnya (Bobek dan Hatfield 2003 dalam Mustikasari 2007). Artinya, semakin kuat tingkat kendali yang dimilki seorang wajib pajak untuk menampilkan perilaku kepatuhan pajak maka 
akan semakin patuh wajib pajak tersebut. Ajzen (2002) mengatakan bahwa kontrol keperilakuan yang dipersepsikan memberikan implikasi motivasi pada individu yang akan berperilaku tersebut. Dalam arti bahwa, niat akan terbentuk apabila individu merasa mampu untuk menampilkan perilaku.

\section{Kewajiban Moral (Moral Obligation)}

Ajzen (1991) menyebutkan bahwa model theory of planned behavior masih memungkinkan untuk ditambahi variabel prediktor lain selain ketiga variabel pembentuk niat. Moralitas adalah hidup yang tertuang dalam perilaku yang benar, yaitu perilaku benar dalam hubungan dengan orang lain maupun dengan diri sendiri (Kurtines dan Gerwitz 1984:14). Cahyonowati (2011) menyebutkan moral perpajakan merupakan motivasi intrinsik wajib pajak untuk mematuhi dan membayar pajak sehingga seharusnya menjadi fokus utama kebijakan otoritas pajak. Kewajiban moral (moral obligation) merupakan norma individu yang dipunyai oleh seseorang yang kemungkinan tidak dimilki oleh orang lain, dimana norma ini secara implisit termasuk dalam model Theory of Planned Behavior (Mustikasari, 2007).

\section{Niat Untuk Patuh (Intention to Comply)}

Niat berperilaku merupakan variabel perantara dalam membentuk perilaku (Ajzen 2002). Dalam Theory of Planned Behavior (TPB), perilaku yang ditampilkan oleh individu timbul karena adanya niat untuk berperilaku. Sedangkan munculnya niat berperilaku ditentukan oleh 3 faktor penentu yaitu behavioral beliefs, normative beliefs dan control beliefs.

Pada umumnya manusia bertindak sesuai dengan niat atau tendensinya. Niat wajib pajak untuk patuh merupakan suatu keadaan dimana seorang wajib pajak memiliki kecenderungan atau keputusan untuk berperilaku patuh pada ketentuan perpajakan. Kecenderungan adalah kecondongan atau tendensi pribadi wajib pajak untuk patuh atau tidak patuh dalam melaksanakan kewajiban perpajakannya. Keputusan adalah keputusan pribadi yang dipilih wajib pajak untuk mematuhi atau tidak mematuhi aturan perpajakan (Harisnani 2011:28 dalam Pangestu dan Rusmana 2012).

\section{Pengaruh Sikap Terhadap Niat untuk Patuh}

Sikap mempengaruhi arah perilaku seseorang apakah mendukung (favorable) atau tidak mendukung (unfavorable) terhadap suatu objek sikap. Sikap mempunyai peran yang penting dalam menje- laskan perilaku seseorang dalam lingkungannya (Mustikasari 2007). Seseorang yang mendukung atas suatu objek sikap akan memiliki kecenderungan bertindak untuk melakukan tindakan terhadap objek sikap. Seseorang wajib pajak yang mendukung (bersikap positif) terhadap tindakan kepatuhan pajak akan memiliki kecenderungan untuk melakukan tindakan kepatuhan pajak. Begitupula sebaliknya, seorang wajib pajak yang tidak mendukung (bersikap negatif) terhadap tindakan kepatuhan pajak akan memiliki kecenderungan untuk tidak melakukan tindakan kepatuhan pajak (Miladia 2010). Dengan kata lain semakin positif sikap wajib pajak terhadap kepatuhan pajak maka semakin kuat niat wajib pajak untuk patuh (Nurina 2010).

Penelitian Mustikasari (2007) berhasil membuktikan bahwa sikap berpengaruh positif terhadap niat untuk berperilaku. Tax professional yang memiliki sikap terhadap ketidakpatuhan positif, niat ketidakpatuhan pajaknya tinggi. Pangestu dan Rusmana (2012) juga menemukan bahwa sikap berpengaruh terhadap niat wajib pajak untuk patuh. Semakin positif sikap wajib pajak untuk patuh terhadap pajak, maka niat wajib pajak untuk patuh semakin besar.

H1 : sikap mempengaruhi niat untuk patuh secara positif.

\section{Pengaruh Norma Subyektif terhadap Niat untuk Patuh}

Penelitian tentang kepatuhan wajib pajak menunjukkan bahwa teman sejawat mempunyai pengaruh penting untuk memprediksi perilaku wajib pajak (Jackson dan Milliron 1986; Roth et al., 1989; Steenbergen, McGraw dan Scholz 1992 dalam Mustikasari 2007). Indikator norma subyektif yang digunakan Bobek \& Hatfield (2003) yaitu anggota keluarga, pimpinan perusahaan, teman, pasangan (Hanno dan Violette 1996) indikator yang digunakan yaitu keluarga telah membuktikan secara empiris bahwa norma subyektif secara positif mempengaruhi niat ketidakpatuhan wajib pajak (Mustikasari 2007). Norma subyektif membentuk niat tax professional untuk berperilaku patuh (pengaruh orang-orang yang dianggap penting disekitar tax professional) (Miladia 2010). Penelitian Oktavia (2009) dan Fauziawati dan Minova (2012) menemukan bahwa norma subyektif berpengaruh positif terhadap niat berperilaku. Hal ini disebabkan karena keinginan atau niat seseorang dipengaruhi oleh lingkungan tempat wajib pajak itu berada.

H2: norma subyektif mempengaruhi niat untuk patuh secara positif 
Pengaruh Kontrol Keperilakuan yang Dipersepsikan terhadap Niat untuk Patuh

Penelitian yang dilakukan oleh Mustikasari (2007) menemukan bahwa kontrol keperilakuan yang dipersepsikan berpengaruh positif terhadap niat tax professional untuk berperilaku tidak patuh. Hal ini menunjukkan semakin rendah persepsi tax professional atas kontrol yang dimilikinya akan mendorong tax professional berniat patuh. Pangestu dan Rusmana (2012) juga menemukan bahwa kontrol keperilakuan yang dipersepsikan berpengaruh terhadap niat wajib pajak untuk patuh. Hal ini menunjukkan bahwa semakin tinggi persepsi wajib pajak atas kendali dan kesanggupan yang dimilikinya akan mendorong niat wajib pajak untuk patuh.

H3 : kontrol keperilakuan yang dipersepsikan mempengaruhi niat untuk patuh secara positif

\section{Pengaruh Kewajiban Moral Terhadap Niat untuk Patuh}

Penelitian yang dilakukan oleh Mustikasari (2007) dan Oktavia (2009) menunjukkan bahwa kewajiban moral berpengaruh negatif terhadap niat berperilaku tidak patuh. Hal ini menunjukkan pernyataan kewajiban moral terhadap ketidakpatuhan pajak yaitu tindakan yang melanggar etika, perasaan bersalah, dan prinsip hidup merupakan indikator yang membentuk kewajiban moral. Sehingga hipotesis yang diajukan dalam penelitian ini yaitu:

H4 : kewajiban moral mempengaruhi niat untuk patuh secara positif

\section{Pengaruh Niat untuk Patuh terhadap Tax Com- pliance (Kepatuhan Pajak)}

Wajib pajak yang memiliki niat untuk patuh yang tinggi maka kepatuhan pajaknya tinggi. Penelitian yang dilakukan oleh Mustikasari (2007), Oktavia (2009), Miladia (2010) serta Pangestu dan Rusmana (2012) berhasil membuktikan bahwa niat untuk patuh berpengaruh positif terhadap kepatuhan pajak (tax compliance). Hal ini berarti bahwa wajib pajak yang memiliki niat untuk patuh yang tinggi, kepatuhan pajaknya pun tinggi.sehingga hipotesis yang diajukan dalam penelitian ini yaitu: H5 : niat untuk patuh mempengaruhi tax compliance secara positif.
Gambar 2. Model penelitian

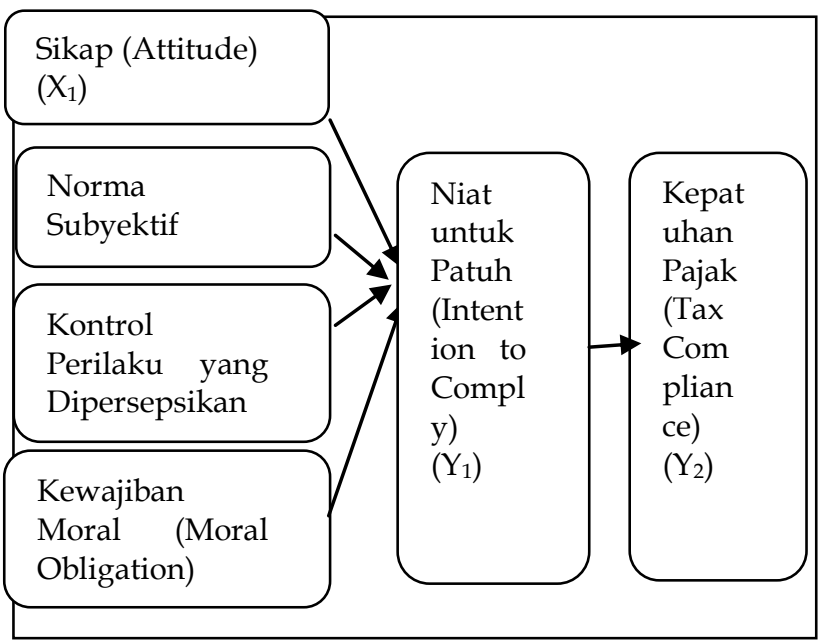

Penelitian ini merupakan penelitian asosiatif dengan hubungan kausal, dengan menggunakan metode survey. Survey ini dilakukan di terhadap wajib pajak orang pribadi mapupun badan yang terdaftar pada KPP di Kota Palembang dengan memberikan kuesioner yang diadopsi dari penelitian Mustikasari (2007). Populasi dalam penelitian ini adalah seluruh wajib pajak orang pribadi maupun badan yang terdaftar pada KPP di Kota Palembang per Juni tahun 2015. Sampel diambil sebanyak 100 responden yang berhasil ditemui. Data dalam penelitian ini adalah data kuantitatif dengan sumber data primer.

Definisi operasional dan pengukuran variabel indikator masing-masing variabel yang mempengaruhi niat dan perilaku diperoleh dari hasil exploratory-test atau yang dalam TPB sering disebut sebagai belief elicitation procedures (BEP) yang dikembangkan oleh mustikasari (2007). Definisi operasional masing-masing variabel disajikan sebagai berikut:

\section{Sikap (Attitude)}

Sikap adalah suatu bentuk perasaan seseorang apakah mendukung atau memihak (favorable) maupun tidak mendukung atau tidak memihak (unfavorable) terhadap suatu obyek. Pengukuran variabel sikap menggunakan 4 indikator pertanyaan dengan kerangka penilaian harapan (valuation-expectancy framework). Pernyataan pertama untuk mengukur belief strength. Pernyataan kedua berkaitan dengan outcome evaluation (Mustikasari 2007).

\section{Norma Subjektif (Subjective Norm)}

Norma subyektif merupakan fungsi dari harapan yang dipersepsikan individu dimana satu atau lebih orang disekitarnya (misalnya, teman, 
keluarga, pimpinan, dan petugas pajak) menyetujui perilaku tertentu dan memotivasi individu tersebut untuk mematuhi mereka (Ajzen 1991). Pengukuran variabel norma subjektif menggunakan 3 indikator. Pernyataan pertama berkaitan dengan normative beliefs, dan yang kedua berkaitan dengan motivation to comply, kedua jawaban ini kemudian dikalikan (mustikasari 2007).

\section{Kontrol Keperilakuan yang Dipersepsikan (Per- ceived Behavioral Control)}

Kontrol keperilakuan adalah seberapa kuat tingkat kendali yang dimiliki seorang wajib pajak dalam menampilkan perilaku tertentu (Mustikasari 2007). Pengukuran variabel kontrol keperilakuan yang dipersepsikan menggunakan 3 indikator. Pernyataan pertama mengukur control beliefs strength dan yang kedua berkaitan dengan control beliefs power.

\section{Kewajiban moral (moral obligation)}

Kewajiban moral adalah norma individu yang dipunyai oleh seseorang, namun kemungkinan tidak dimiliki oleh orang lain (Mustikasari 2007). Pengukuran variabel kewajiban moral meggunakan 3 indikator yang diadopsi dari penelitian Mustikasari (2007).

\section{Niat untuk patuh (intention to comply)}

Niat wajib pajak untuk patuh merupakan suatu keadaan dimana seorang wajib pajak memiliki kecenderungan atau keputusan untuk berperilaku patuh pada ketentuan perpajakan (Harisnani 2011:28 dalam Pangestu dan Rusmana 2012). Pengukuran variabel niat berperilaku untuk patuh menggunakan 2 indikator yaitu kecenderungan dan keputusan (Mustikasari 2007).

\section{Tax compliance (kepatuhan pajak)}

Kepatuhan adalah keadaan wajib pajak yang melaksanakan hak, dan khususnya kewajibannya, secara disiplin sesuai peraturan perpajakan yang berlaku. Wajib pajak dikatakan patuh apabila melaporkan semua informasi yang diperlukan tepat waktu, mengisi secara benar jumlah pajak terutang, dan membayar pajak tepat pada waktunya (pangestu dan rusmana 2012). Pengukuran variabel tax compliance (kepatuhan pajak) menggunakan 4 indikator yang diadopsi dari penelitian Brown dan Mazur dalam Mustikasari (2007) (Lihat Tabel 1 di Lampiran).

\section{HASIL DAN PEMBAHASAN}

\section{Uji Instrumen Penelitian}

Uji validitas digunakan untuk mengukur sah atau valid tidaknya suatu kuesioner. berdasarkan uji validitas, tampak bahwa semua nilai $r$ tabel pada semua butir pertanyaan memiliki nilai diatas nilai $r$ tabel. sehingga dapat disimpulkan bahwa emua butir pernyataan adalah valid. reliabilitas adalah alat untuk mengukur suatu kuesioner yang merupakan indikator dari variabel atau konstruk (Ghozali 2005). berdasarkan nilai alpha simultan (komposit) pada hasil pengujian reliabilitas, terlihat bahwa semua nilai tersebut lebih besar dari nilai $r$ tabel. selain itu, semua nilai cronbach's alpha lebih besar dari 0,6. berdasarkan hasil tersebut maka dapat disimpulkan bahwa secara komposit semua item pernyataan adalah reliable.

\section{Uji Asumsi Klasik}

Uji asumsi klasik digunakan pada penelitian yang menggunakan teknik analisis regresi linier berganda agar data-data terbebas dari gejala normalitas, multikolinieritas, heterokedastisitas dan autokorelasi. hasil uji normalitas menunjukkan bahwa nilai asymp.sig bernilai 0,226 . nilai tersebut lebih besar dari nilai signifikansi 0,05 (5\%), sehingga dapat disimpulkan bahwa data berdistribusi normal. uji multikolinearitas bertujuan untuk menguji apakah model regresi ditemukan adanya korelasi antar variabel bebas (independen). hasil uji multikolinieritas menunjukkan bahwa semua nilai tolerance setiap variabel berada di atas 0,1 dan semua nilai vip setiap variabel berada di bawah nilai 10. berdasarkan hasil tersebut, maka dapat disimpulkan bahwa data terbebas dari masalah multikolinieritas.

Uji heterokedastisitas bertujuan menguji apakah dalam model regresi terjadi ketidaksamaan varian dari residual satu pengamatan ke pengamatan yang lain. Hasil dari pengujian heterokedastisitas menunjukkan bahwa nilai signifikansi semua variabel lebih besar dari 0,05, sehingga dapat disimpulkan bahwa data bebas dari gejala heterokedastisitas. Uji autokorelasi digunakan untuk mengetahui ada atau tidaknya residual pada satu pengamatan dengan pengamatan lain pada model regresi. Hasil pengujian menunjukkan bahwa nilai durbin-watson menunjukkan nilai 2,196.sedangkan dari tabel $\mathrm{dw}$ dengan signifikansi 0,05 dengan jumlah data $(n)=100$ dan jumlah variabel independen $(\mathrm{k})=4$, menghasilkan nilai $\mathrm{dl}$ sebesar 1,592 dan du =1,758. Karena nilai dw ter- 
letak antara du dan 4-du, berarti dapat disimpulkan bahwa data bebas dari autokorelasi.

\section{Uji Hipotesis}

Dari tabel 2, hubungan antara sikap, norma subyektif, kontrol keprilakuan yang dipersepsikan dan kewajiban moral terhadap niat untuk patuh dapat dijelaskan sebagai berikut : variabel sikap, nilai $t$ hitung sebesar $-1,182<t$ tabel sebesar 1,6602 dengan tingkat signifikansi $0,20>0,05$ yang berarti bahwa variabel sikap tidak mempengaruhi variabel niat untuk patuh. Variabel norma subjektif, nilai $t$ hitung sebesar $-1,348<t$ tabel sebesar 1,6602 dengan tingkat signifikansi $0,181>0,05$ yang berarti bahwa variabel norma subjektif tidak mempengaruhi variabel niat untuk patuh.

Variabel kontrol keprilakuan yang dipersepsikan, nilai $\mathrm{t}$ hitung sebesar 2,655 $>\mathrm{t}$ tabel sebesar 1,6602 dengan tingkat signifikansi 0,009 $<0,05$ yang berarti bahwa variabel control keprilakuan yang dipersepsikan mempengaruhi variabel niat untuk patuh. Variabel kewajiban moral, nilai t hitung sebesar 2,366 $>\mathrm{t}$ tabel sebesar 1,6602 dengan tingkat signifikansi 0,020 $<0,05$ yang berarti bahwa variabel kewajiban moral mempengaruhi variabel niat untuk patuh.

Hubungan antara niat untuk patuh dengan kepatuhan wajib pajak dapat dijelaskan sebagai berikut : nilai $t$ hitung sebesar $9,450>t$ tabel sebesar 1,6602 dengan tingkat signifikansi 0,00<0,05 yang berarti bahwa variabel niat untuk patuh mempengaruhi variabel kepatuhan wajib pajak.

Hubungan antara niat untuk patuh dengan kepatuhan wajib pajak dapat dijelaskan sebagai berikut : nilai $t$ hitung sebesar $9,450>t$ tabel sebesar 1,6602 dengan tingkat signifikansi $0,00<0,05$ yang berarti bahwa variabel niat untuk patuh mempengaruhi variabel kepatuhan wajib pajak.

Hasil uji F (lihat Tabel 2 di lampiran) menunjukkan bahwa pengaruh sikap, norma subyektif, kontrol keprilakuan yang dipersepsikan dan kewajiban moral terhadap niat untuk patuh dapat dijelaskan sebagai berikut : nilai $\mathrm{F}$ hitung sebesar 3,164 > F tabel sebesar 1,6602 dengan tingkat signifikansi 0,017 < 0,05 yang berarti bahwa model penelitian sudah baik. Sikap, norma subjektif, control keprilakuan yang dipersepsikan dan kewajiban moral secara serentak atau simultan mempengaruhi niat untuk patuh. Lebih lanjut, model penelitian pengaruh niat untuk patuh dengan kepatuhan wajib pajak sudah baik, ini terlihat dengan melihat nilai $\mathrm{F}$ hitung sebesar 89,30 $>\mathrm{t}$ tabel sebesar 1,6602 dengan tingkat signifikansi 0,00 $<0,05$.
Berdasarkan hasil pengujian diperoleh nilai nilai Adjusted $\mathrm{R}$ Square pada model atau persamaan pertama bernilai 0,080 atau $8 \%$. Hasil ini menggambarkan bahwa variabel sikap, norma subjektif, control keprilakuan yang dipersepsikan dan kewajiban moral hanya mempengaruhi niat untuk patuh sebesar $8 \%$, sisanya sebesar $94 \%$ dipengaruhi oleh variabel yang tidak dimasukkan dalam model penelitian. Artinya, masih banyak faktor-faktor lain yang mempengaruhi niat wajib pajak untuk patuh dalam memenuhi kewajiban perpajakannya. Nilai R Square pada model atau persamaan kedua menunjukkan hasil 0,471 atau $(47,1 \%)$. Nilai ini menunjukkan bahwa variabel kepatuhan wajib pajak dipengaruhi oleh variabel niat untuk patuh sebesar $47,1 \%$, sisanya sebesar $52,9 \%$ dipengaruhi faktor lain yang tidak dimasukkan dalam model penelitian.

\section{PEMBAHASAN}

\section{Pengaruh Sikap terhadap Niat untuk Patuh}

Berdasarkan hasil pengujian hipotesis pertama untuk variabel sikap menunjukkan bahwa sikap tidak mempengaruhi niat untuk patuh. Sehingga hipotesis pertama yang menyatakan bahwa sikap mempengaruhi niat untuk patuh secara positif adalah ditolak. Artinya, secara statitik dapat ditunjukkan bahwa sikap tidak memiliki pengaruh terhadap niat untuk patuh. Hasil penelitian ini tidak sejalan dengan penelitian yang dilakukan oleh Pangestu dan Rusmana (2012) yang menunjukan bahwa sikap berpengaruh terhadap niat wajib pajak untuk patuh.

Sikap merupakan produk dari proses sosialisasi di mana seseorang bereaksi sesuai dengan rangsang yang diterimanya (Mar'at 1981:9). Sikap seseorang terhadap suatu objek adalah perasaan mendukung atau memihak (favorable) maupun perasaan tidak mendukung atau tidak memihak (unfavorable) pada obyek tersebut (Mustikasari 2007). Seseorang yang memiliki sikap positif maka niat yang dimilikinya akan positif pula. Artinya seseorang yang memiliki sikap untuk patuh yang besar maka niat untuk patuh yang dimilikinya juga akan semakin besar.

Namun penelitian ini menunjukkan hasil yang berbeda. Niat untuk patuh tidak dipengaruhi oleh sikap seseorang. Niat untuk patuh lebih cenderung diakibatkan seberapa kuat kontrol atau tingkat kendali yang dimiliki seorang wajib pajak dalam menampilkan perilaku tertentu serta norma individu yang timbul dalam diri seseorang. 
Pengaruh norma subyektif terhadap niat untuk patuh

Berdasarkan hasil pengujian hipotesis kedua untuk variabel norma subyektif menunjukkan bahwa norma subyektif tidak mempengaruhi niat untuk patuh. Sehingga hipotesis kedua yang menyatakan bahwa norma subyektif mempengaruhi niat untuk patuh secara positif adalah ditolak. Artinya, norma subyektif tidak mempengaruhi niat untuk patuh wajib pajak orang pribadi dan badan. Hasil penelitian ini sejalan dengan penelitian yang dilakukan oleh Pangestu dan Rusmana (2012) yang menunjukkan bahwa norma subyektif tidak berpengaruh terhadap niat wajib pajak untuk patuh.

Norma subyektif merupakan persepsi individu tentang pengaruh sosial dalam membentuk perilaku tertentu (Ajzen 1988 dalam Mustikasari 2007). Semakin tinggi pengaruh sosial (orangorang disekitar) maka mempengaruhi niat yang dimiliki oleh orang tersebut. Akan tetapi apabila seseorang memiliki keyakinan yang tinggi dalam dirinya maka niat tersebut tidak akan mudah terpengaruh oleh orang lain. Wajib pajak memiliki niat untuk patuh terhadap perpajakan maka pengaruh orang-orang sekitar wajib pajak tidak akan mempengaruhi niat untuk patuh tersebut.

\section{Pengaruh Kontrol Keperilakuan yang Dipersep- sikan}

Berdasarkan hasil pengujian hipotesis ketiga untuk variabel kontrol keperilakuan yang dipersepsikan menunjukkan bahwa kontrol keperilakuan yang dipersepsikan mempengaruhi niat untuk patuh secara positif. Sehingga hipotesis ketiga yang menyatakan bahwa kontrol keperilakuan yang dipersepsikan mempengaruhi niat untuk patuh diterima secara positif adalah diterima. Artinya, kontrol keperilakuan yang dipersepsikan memiliki pengaruh terhadap niat untuk patuh wajib pajak orang pribadi dan badan. Hasil penelitian ini tidak sejalan dengan penelitian yang dilakukan oleh Pangestu dan Rusmana (2012) yang menyatakan bahwa kontrol keperilakuan yang dipersepsikan berpengaruh terhadap niat wajib pajak untuk patuh.

Kontrol keperilakuan yang dipersepsikan adalah seberapa kuat tingkat kendali yang dimiliki seorang wajib pajak dalam menampilkan perilaku tertentu (Bobek dan Hatfield, 2003 dalam Mustikasari 2007). Seorang wajib pajak yang memiliki kontrol keperilakuan yang dipersepsikan yang tinggi maka perilaku patuh yang akan ditampilkannya akan tinggi. Begitupula sebaliknya seorang wajib pajak yang memiliki kontrol keperilakuan yang dipersepsikan yang rendah maka perilaku kepatuhannya juga akan rendah pula.

\section{Pengaruh Kewajiban Moral Terhadap Niat Untuk Patuh}

Berdasarkan hasil pengujian hipotesis keempat untuk variabel kewajiban moral menunjukkan bahwa kewajiban moral mempengaruhi niat untuk patuh secara positif. sehingga hipotesis ketiga yang menyatakan bahwa kewajiban moral mempengaruhi niat untuk patuh secara positif adalah diterima. artinya, wajib pajak orang pribadi dan badan yang memiliki kewajiban moral positif yang tinggi maka niat untuk patuhnya juga tinggi. hasil penelitin ini tidak sejalan dengan penelitian yang dilakukan oleh Mustikasari (2007) yang menemukan bahwa kewajiban moral berpengaruh negatif terhadap niat.

Kewajiban moral merupakan norma individu yang dipunyai oleh seseorang yang kemungkinan tidak dimiliki oleh orang lain (Mustikasari 2007). seseorang yang memiliki kewajiban moral yang positif terhadap ketentuan perpajakan maka niat untuk patuh terhadap ketentuan perpajakan akan tinggi. sebaliknya jika seseorang memiliki kewajiban moral yang negatif terhadap ketentuan perpajakan maka niat untuk patuh terhadap ketentuan perpajakannya akan rendah.

\section{Pengaruh Niat untuk Patuh terhadap Tax Compliance (Kepatuhan Pajak)}

Berdasarkan hasil pengujian hipotesis kelima untuk variabel niat untuk patuh menunjukkan bahwa niat untuk patuh mempengaruhi tax compliance secara positif. Sehingga hipotesis kelima yang menyatakan bahwa niat untuk patuh mempengaruhi tax compliance secara positif adalah diterima. Artinya, tax compliance (kepatuhan pajak) dipengaruhi oleh niat yang dimiliki oleh Wajib Pajak Orang Pribadi dan Badan. Hasil penelitian ini sejalan dengan penelitian yang dilakukan oleh Pangestu dan Rusmana (2012) yang menemukan bahwa niat wajib pajak untuk patuh berpengaruh terhadap tax coompliance. Penelitian ini tidak mendukung hasil penelitian Fauziawati dan Minova (2012) yang menemukan bahwa niat tidak berpengaruh terhadap kepatuhan pajak.

Niat wajib pajak untuk patuh merupakan suatu keadaan dimana seorang wajib pajak memiliki kecenderungan atau keputusan untuk berperilaku patuh pada ketentuan perpajakan 
(Harisnani 2011:28 dalam Pangestu dan Rusmana 2012). Kecenderungan atau keputusan untuk berperilaku patuh menimbulkan perilaku wajib pajak untuk patuh terhadap kewajiban perpajakan. Wajib pajak orang pribadi dan badan di Kota Palembang pada dasarnya memilki niat untuk patuh yang cukup besar dan niat tersebut terwujud dengan kepatuhan mereka terhadap kwajiban perpajakan. Jadi, selain dikarenakan takut akan sanksi perpajakan, Wajib Pajak tersebut memang memiliki niat yang tulus untuk patuh dalam hal memenuhi kewajiban perpajakan.

\section{KESIMPULAN}

Berdasarkan uraian di atas, maka dapat ditarik kesimpulan bahwa:

Secara parsial variabel sikap dan variabel norma subjektif tidak mempengaruhi niat untuk patuh Wajib Pajak Orang Pribadi dan Badan dalam hal penyampaian SPT Tahunan Pajak Pengahsilan. Sementara variabel kontrol keperilakuan yang dipersepsikan dan variabel kewajiban moral mempengaruhi niat untuk patuh secara positif Wajib Pajak Orang pribadi dan Badan dalam hal menyampaikan SPT Tahunan Pajak Penghasilan.

Niat untuk patuh mempengaruhi tax compliance (kepatuhan pajak) secara positif Wajin Pajak Orang Pribadi dan Badan dalam menyampaikan SPT Tahunan Pajak Penghasilan.

Penelitian ini memiliki beberapa keterbatasan dan saran yang perlu untuk diperhatikan dan dipertimbangkan yaitu:

Ruang lingkup penelitian hanya terbatas pada Wajib Pajak Orang Pribadi dan Badan yang terdaftar pada KPP di Kota Palembang dalam hal penyampaian SPT Tahunan Pajak Penghasilan. Sehingga hasil penelitian tidak dapat digeneralisir ke semua objek. Penelitian selanjutnya dapat memperluas sampel penelitian dan dapat menguji tax compliance dalam hal penyampaian SPT Masa PPN.

Penelitian ini hanya menguji 6 variabel yaitu sikap, norma subyektif, kontrol keperilakuan yang dipersepsikan, kewajiban moral, niat untuk patuh dan tax compliance padahal pada kenyataannya dilapangan masih banyak faktor-faktor yang dapat mempengaruhi tax compliance. Penelitian selanjutnya dapat menambah variabel yang kemungkinan relevan dan cocok dengan penelitian serupa seperti menambahkan variabel kesadaran wajib pajak, pengetahuan aturan perpajakan dan sanksi pajak karena niat dan perilaku patuh wajib pajak tidak hanya terbatas pada faktor-faktor internal yang terdapat di dalam diri wajib pajak namun terdapat faktor eksternal yang dapat mempengaruhinya.

Teknik pengumpulan data terbatas hanya dengan menggunakan kuesioner sehingga kurang dapat menggali informasi dari responden. Penelitian selanjutnya dapat menambah teknik pengumpulan data dengan melakukan teknik wawancara sehingga informasi yang didapatkan akan lebih luas dan informatif.

\section{REFERENSI}

Ajzen, Icek. 1991. The Theory of Planned Behavior: Organizational Behavior and Human Decision Processes. Vol. 50. Hlm. 179-211. University of Massachusetts at Amhest: Academic Press. Inc.

.--- 2002. Constructing a TPB Questionnaire: Conceptual and Methodological Consideration. September (Revised January, 2006).

Cahyonowati, Nur. 2011. Model Moral Dan Kepatuhan Perpajakan: Wajib Pajak Orang Pribadi. JAAI. Volume 15 No.2, Desember 2011: 161-177.

Diana, Anastasia dan Lilis Setiawati. 2009. Perpajakan Indonesia: Konsep, Aplikasi, dan Penuntun Praktis. Yogyakarta: C.V Andi Offset.

Fauziawati, Popi dan Arie Frinola Minovia. 2012. Analisis Faktor-Faktor yang Mempengaruhi Tingkat Kepatuhan Wajib Pajak dalam Penyetoran SPT Tahunan (Studi Empiris KPP Pratama Padang). Konferensi Ilmiah Akuntansi 2014. Fakultas Ekonomi Universitas Bung Hatta. Padang. www.academia.edu. Diakses 28 November 2014.

Ghozali, Imam. 2005. Aplikasi Analisis Multivariate Dengan Program SPSS. Semarang: Badan Penerbit Universitas Diponegoro.

Harinurdin, Erwin. 2009. Perilaku Kepatuhan Wajib Pajak Badan. Jurnal Ilmu Administrasi dan Organisasi, Bisnis \& Birokrasi, Volume 16, Nomor 2, hlm. 96-104 (Mei - Agustus). 
http://www.kemenkeu.go.id/Data/rapbn-tahun2015. Diakses pada 9 Januari.

http://www.republika.co.id/berita/ekonomi/ma kro/14/09/09/nble57-kepatuhan-wajibpajak-masih-minim. Diakses pada 4 Januari 2015.

http:/ /economy.okezone.com/read/2015/01/14/ 20/1092108/penerimaan-pajak-2014terendah-selama-25-tahun. Diakses pada 3 Maret 2015.

http:/ finansial.bisnis.com/read/20140803/10/24 7248/ekonom-bank-dunia-orang-kaya-diindonesia-kurang-patuh-bayar-pajak, diakses 20 Oktober 2015

Judisseno, Rimsky K. 2002. Pajak dan Strategi Bisnis: Suatu Tinjauan tentang Kepastian Hukum dan Penerapan Akuntansi di Indonesia. Jakarta: PT Gramedia Pustaka Utama.

Kurtines, William M dan Jacob L. Gerwitz. 1984. Morality, Moral Behavior, And Moral Development. John Wiley \& Sons, Inc. USA. Terjemahan M.I. Soelaeman. 1992. Moralitas, Perilaku Moral, Dan Perkembangan Moral. Cetakan Pertama. Jakarta: Penerbit Universitas Indonesia.

Mandiri, Devia Agustriana., Tarjo dan Nurul Herawati. 2009. Analisis Faktor-Faktor yang Mempengaruhi Perilaku Ketidakpatuhan Wajib Pajak Orang Pribadi Di Bangkalan. Simposium Nasional Perpajakan 2. Trunojoyo.

Mar'at. 1981. Sikap Manusia Perubahan serta Pengukurannya. Bandung: Ghalia Indonesia.

Miladia, Novita. 2010. Analisis Faktor-Faktor yang Mempengaruhi Tax Compliance Wajib Pajak Badan Pada Perusahaan Industri Manufaktur di Semarang. Skripsi. Fakultas Ekonomi Universitas Diponogoro. Semarang.
Mustikasari, Elia. 2007. Kajian Empiris tentang Kepatuhan Wajib Pajak Badan di Perusahaan Industri Pengolahan di Surabaya. Simposium Nasional Akuntansi X. Makasar. Hal. 1-41.

Nota Keuangan dan Rancangan Anggaran Pendapatan Dan Belanja Negara Tahun Anggaran 2015.

Nurina, Latifah. 2010. Kajian Empiris Tentang Kepatuhan Wajib Pajak Orang Pribadi Di Kota Surakarta. Skripsi. Fakultas Ekonomi Universitas Sebelas Maret. Surakarta.

Oktavia, Francisca Deby. 2009. Analisis FaktorFaktor yang Mempengaruhi Niat Berperilaku Tidak Patuh terhadap Ketidakpatuhan Pajak Badan. Rangkuman Skripsi. Sekolah Tinggi Ilmu Ekonomi Perbanas. Surabaya. 


\section{LAMPIRAN}

Tabel 1. Variabel dan Indikatornya

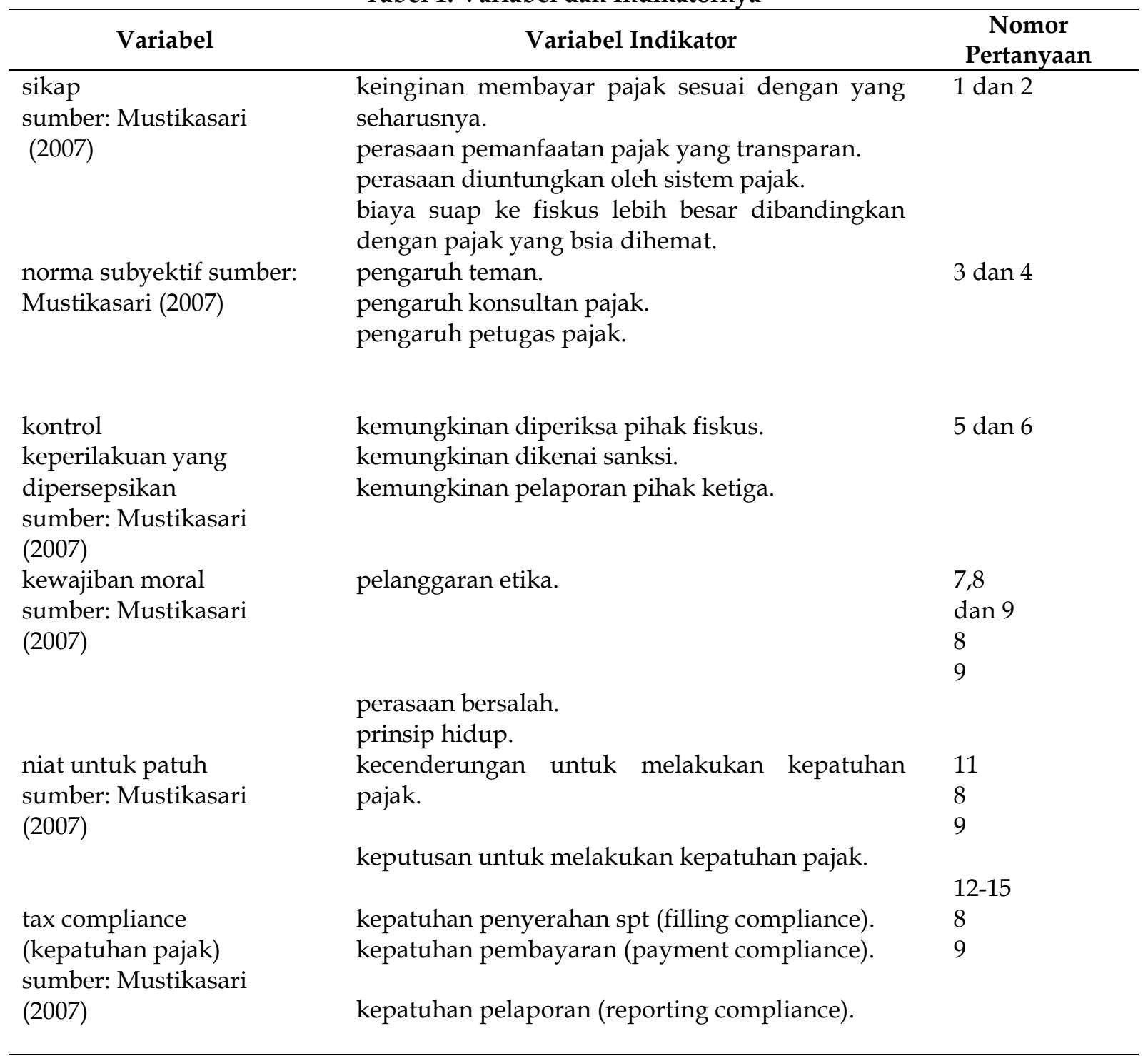

sumber: data sekunder (diolah)

Tabel 2. Hasil Uji Individual (uji t)

\begin{tabular}{lllllll}
\hline \multirow{2}{*}{ Model } & \multicolumn{3}{c}{ Standardized } \\
& $\begin{array}{c}\text { Unstandardized Coefficients } \\
\text { Variabel (X) }\end{array}$ & B & Std. Error & Beta & $\mathrm{t}$ & sig \\
\hline \multirow{3}{*}{ Y= Niat Patuh } & SIKAP & $-0,174$ & 0,585 & $-0,123$ & $-1,182$ & 0,240 \\
& NORMA & $-0,164$ & 0,147 & $-0,143$ & $-1,348$ & 0,181 \\
& KONTROL & 0,419 & 0,122 & 0,286 & 2,655 & 0,009 \\
Y= Kepatuhan & MORAL & 0,273 & 0,115 & 0,245 & 2,366 & 0,020 \\
\hline
\end{tabular}

